\title{
Efektivitas Sediaan Salep Limbah Kulit Singkong Sebagai Penyembuh Luka
}

\author{
Effectiveness of Cassava Skin Ointment as Wound Healer
}

\author{
Widia Nila Risnadewi*, Nadya Arianita Turisia, Alsifah Nurhidayati, \\ Candra Dwipayana Hamdin \\ Program Studi Farmasi, Fakultas kedokteran, Universitas Mataram \\ Jl. Majapahit 62 Mataram 83125, Telp. (0370) 646506 INDONESIA \\ *corresponding author, email: widianila@gmail.com
}

Manuscript received: 17-09-2019. Accepted: 27-12-2019

\begin{abstract}
ABSTRAK
Kulit merupakan organ penting yang berfungsi untuk menerima rangsangan seperti sentuhan, rasa sakit serta pengaruh lainnya dari luar. Beberapa masalah yang terjadi pada bagian kulit dapat disebabkan karena kulit sangat rentan terhadap trauma dan terjadinya luka. Luka merupakan suatu keadaan terputusnya keutuhan jaringan yang disebabkan oleh kekerasan baik bersifat mekanik, fisika dan kimia. Pada umumnya perawatan luka di masyarakat dilakukan dengan balutan disertai dengan kompres betadine dan normal saline karena bahan-bahan tersebut mudah didapatkan. Namun penggunaan jangka panjang balutan tersebut dapat menyebabkan penyembuhan luka yang lambat dan dapat muncul berbagai infeksi. Hal ini menyebabkan masyarakat mencari alternatif pengobatan lain salah satunya dengan tanaman herbal yakni tanaman singkong memiliki potensi untuk dimanfaatkan sebagai penyembuh luka dan mampu menghambat bakteri karena diduga mengandung senyawa fenolik. Penelitian ini merupakan penelitian true experimental, kelompok hewan uji dibagi 6 kelompok, setelah itu pembuatan luka dan dioleskan bakteri diberikan salep dengan 3 konsentrasi yaitu 5\%, 10\%, dan $15 \%$. Salep ekstrak etanol limbah kulit singkong memberikan efek pada proses penyembuhan luka dilihat dari panjang luka. Salep ekstrak etanol yang memberikan efek baik dalam penyembuhan luka adalah salep dengan kosentrasi $10 \%$ dan $15 \%$.
\end{abstract}

Kata kunci: Salep; Bakteri; Fenolik; Ekstrak; Penyembuhan

\begin{abstract}
The skin is an important organ that functions to receive stimuli such as touch, pain and other influences from the outside. Some problems that occur on the skin can becaused because the skin is very vulnerable to trauma and injury. Wound is a condition of the breakdown of tissue integrity caused by violence both mechanical, physical and chemical in nature. In general, wound care in the community is done with a dressing accompanied by compresses betadine and normal saline because these materials are easily available. However, long-term use of the dressing can cause slow wound healing and various infections can appear. This causes people to look for other alternative treatments, one of them with herbal plants, namely cassava plants have the potential to be used as a wound healing and is able to inhibit bacteria
\end{abstract}


because they are suspected to contain phenolic compounds. This study was a true experimental study, the group of test animals was divided into 6 groups, after that the making of wounds and smeared with bacteria were given ointments with 3 concentrations namely $5 \%, 10 \%$, and $15 \%$. Ointment extract of cassava skin waste gives effect to the wound healing process seen from the length of the wound. The ethanol extract ointment which has a good effect on wound healing is an ointment with a concentration of $10 \%$ and $15 \%$.

Keyword: Ointment; Bacteria; Phenolic; Extract; Healing

\section{PENDAHULUAN}

Kulit merupakan organ penting pada tubuh karena terletak pada bagian luar tubuh dan berfungsi untuk menerima rangsangan seperti sentuhan, rasa sakit serta pengaruh lainnya dari luar. Beberapa masalah yang terjadi pada bagian kulit dapat disebabkan karena kulit sangat rentan terhadap trauma dan terjadinya luka (Kawulusan dkk, 2015). Luka merupakan suatu keadaan terputusnya keutuhan jaringan yang disebabkan oleh kekerasan baik bersifat mekanik (benda tumpul, benda tajam, senjata api), fisika (suhu, listrik dan petir, perubahan tekanan udara, akustik, radiasi) maupun kimia (asam atau basa kuat) (Venita, 2014).

Pada umumnya perawatan luka di masyarakat dilakukan dengan balutan disertai dengan kompres betadine dan normal saline karena bahan-bahan tersebut mudah didapatkan. Namun penggunaan jangka panjang balutan tersebut dapat menyebabkan penyembuhan luka yang lambat dan dapat muncul berbagai infeksi. Hal ini menyebabkan masyarakat mencari alternatif pengobatan lain salah satunya dengan tanaman herbal. Penggunaan tanaman herbal semakin digemari oleh masyarakat dengan adanya trend back to nature (Mutiara, 2015).

Singkong merupakan tanaman yang memiliki banyak manfaat, salah satunya adalah bahan pangan pokok setelah beras. Produksi singkong di Indonesia mencapai 21 juta ton pada tahun 2015. Singkong dengan bagian kulit memiliki porsi $20 \%$ dari tiap kilogram umbi singkong, maka terdapat kurang lebih 4 juta ton kulit singkong yang terbuang menjadi limbah. Sedangkan produksi singkong di NTB dari tahun 1993-2005 terus meningkat. Pada tahun 2015 mencapai 107.254 ton (BPS, 2015). Tingginya angka produksi tersebut dapat meningkatkan jumlah limbah kulit singkong. Faktanya, limbah tersebut sampai saat ini belum dapat diselesaikan dan menimbulkan masalah seperti pencemaran lingkungan.

Berdasarkan hal tersebut, kulit singkong memiliki potensi untuk dimanfaatkan sebagai penyembuh luka dan mampu menghambat bakteri karena diduga mengandung senyawa fenolik. Salah satu bentuk sediaan yang dapat dibuat dari limbah kulit singkong adalah sediaan salep yang memiliki beberapa keuntungan diantaranya pemakaian yang mudah tanpa alat bantu, lebih sedikit mengandung air sehingga sulit ditumbuhi bakteri serta kontak sediaan dengan kulit lebih lama. Oleh karena itu, perlu dilakukan penelitian untuk membuktikan efektifitas sediaan salep limbah kulit singkong sebagai penyembuh luka.

\section{BAHAN DAN METODE}

Penelitian ini merupakan percobaan experimental dengan menggunakan desain post test control group design. Dilaksanakan selama 4 bulan dari bulan April-Juli 2019 di 
Laboratorium Farmakologi Farmasi dan Farmakologi Fakultas Kedokteran Universitas Mataram.

\section{Bahan Tanaman dan Determinasi}

Limbah kulit singkong yang digunakan diperoleh dari pedagang singkong keju di daerah Ampenan, Lombok Barat, NTB. Limbah kulit singkong yang didapat dibersihkan dan dilakukan uji determinasi tanaman berdasarkan ciri-ciri atau bentuk morfologi tanaman di Laboratorium Biologi, Fakultas Matematika dan Ilmu Pengetahuan Alam, Universitas Mataram.

\section{Pembuatan Ekstrak dan Skrining Fitokimia}

Limbah kulit singkong yang telah dibuat simplisia kering kemudian diblender dan dimaserasi selama 3 hari dalam pelarut etanol $96 \%$. Hasil ekstraksi disaring dan dipekatkan dengan rotary evaporator hingga diperoleh berat ekstrak sebanyak 16,19 gram. Ekstrak tersebut dilakukan skrining fitokimia di Laboratorium Biologi, Fakultas Matematika dan Ilmu Pengetahuan Alam, Universitas Mataram.

\section{Pembuatan Salep}

Cetyl alkohol dipanaskan sampai melarut, ditambahkan PEG 4000 dan diaduk hingga homogen. Dalam campuran tersebut, ditambahkan sedikit demi sedikit PEG 400 dan ekstrak kulit singkong sesuai konsentrasi yakni $5 \%, 10 \%$ dan $15 \%$.

\section{Pembuatan Luka Hewan Uji dan Pemberian Salep}

Mencit dibius menggunakan klorofom, kemudian dicukur bulu punggung dengan krim depilatories. Cubit bagian kulit dengan pinset kemudian di eksisi bagian kulit punggung yang sudah ditandai menggunakan pisau steril. Pada luka sayatan tersebut diberikan suspensi Staphylococcus aureus. Setelah 3 hari luka diobati dengan pemberian salep 5\%, $10 \%$ dan 15 $\%$ pada masing-masing kelompok hewan uji.

\section{Determinasi Tumbuhan}

\section{HASIL DAN PEMBAHASAN}

Determinasi dilakukan untuk memastikan kebenaran identitas dari tumbuhan yang digunakan serta menghindari terjadinya kesalahan dalam pengambilan sampel. Untuk memastikan kebenarannya, dilakukan determinasi di Laboratorium Biologi, Fakultas Matematika dan Ilmu Pengetahuan Alam, Universitas Mataram. Berdasarkan surat keputusan nomor 36/UN18.7/LB/2019 membuktikan bahwa memang benar sampel yang digunakan adalah kulit singkong (Manihot utilisima), yang terdiri dari dua lapisan yaitu lapisan kulit luar yang tipis mudah robek dan berwarna coklat, serta lapisan kulit dalam yang memiliki ketebalan 1-3 mm berwana putih (Hikmiyati dan Yantie, 2008). 


\section{Ekstraksi Simplisia Kulit Singkong}

Kulit singkong yang didapat dibuat simplisia dan diekstraksi dengan cara maserasi. Pembuatan simplisia limbah kulit singkong terdiri dari beberapa tahapan yakni pengumpulan bahan baku yang diperoleh dari Pedagang Singkong Keju Daerah Ampenan, Mataram; sortasi basah; pencucian; perajangan; pengeringan; sortasi kering dan penyimpanan simplisia. Simplisia yang diblender kemudian diekstrak dengan metode maserasi menggunakan pelarut etanol $96 \%$ selama 3 hari dan diperoleh volume ekstrak sebanyak 1500 mL. Hasil ekstrak tersebut dipekatkan dengan metode evaporasi hingga diperoleh ekstrak kental sebanyak 16,19 gram dengan \% rendemen berkisar $8,095 \%$.

\section{Skrining Fitokimia}

Hasil uji fitokimia menunjukkan bahwa ekstrak etanol kulit singkong mengandung senyawa fenolik yang bersifat antioksidan seperti tannin, flavonoid dan alkaloid. Hasil ini berdasarkan pada perubahan warna dan pembentukan endapan setelah penambahan reagen.

\begin{tabular}{l|l|l|c|c}
\hline \multicolumn{1}{c|}{ Uji Fitokimia } & \multicolumn{1}{|c|}{ Pereaksi } & \multicolumn{1}{|c|}{ Hasil } & Kesimpulan & Gambar \\
\hline Alkaloid & Dragendorf & Terbentuk endapan & + \\
Flavonoid & $\begin{array}{l}\text { Serbuk Mg }+ \\
\text { HCL }\end{array}$ & $\begin{array}{l}\text { Terbentuk warna } \\
\text { merah atau jingga }\end{array}$ & + \\
Tanin & FeCl $_{3}$ & $\begin{array}{l}\text { Terbentuknya } \\
\text { warna hijau } \\
\text { kehitaman }\end{array}$ & + \\
Saponin & & $\begin{array}{l}\text { Tidak terbentuk } \\
\text { busa yang stabil }\end{array}$ & \\
\hline
\end{tabular}

Pada penelitian ini dibuat salep hidrokarbon 3 formula salep meliputi salep 5\%; 10\% dan $15 \%$. Salep yang diperoleh memiliki karakteristik berwarna putih kecoklatan, bertekstur lembut dan lengket, serta berbau khas obat. 


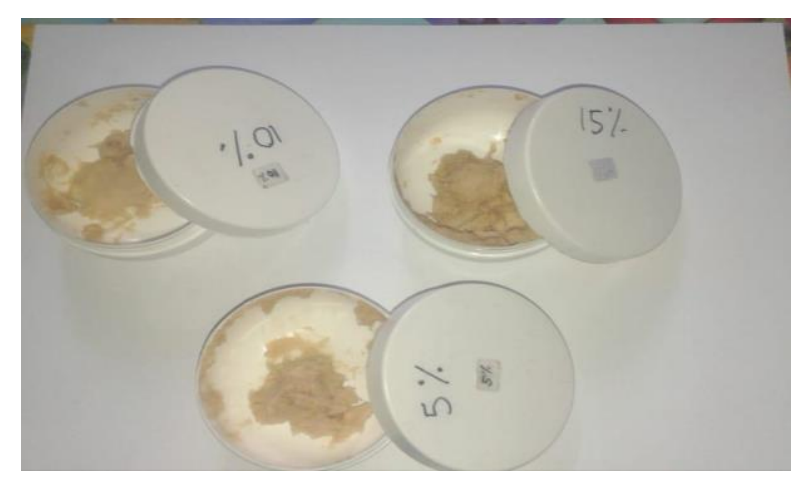

Gambar 1. Salep Ekstrak Kulit Singkong

\section{Pembuatan Panjang Luka}

Luka pada penelitian ini dibuat dengan menyayat bagian punggung mencit sepanjang $1 \mathrm{~cm}$ yang sudah dibersihkan dari bulu. Pembuatan luka sepanjang $1 \mathrm{~cm}$ diikuti dengan pengolesan bakteri Staphylococcus aureus agar luka menjadi infeksi berwarna sedikit kecoklatan.

\section{Penurunan Panjang Luka}

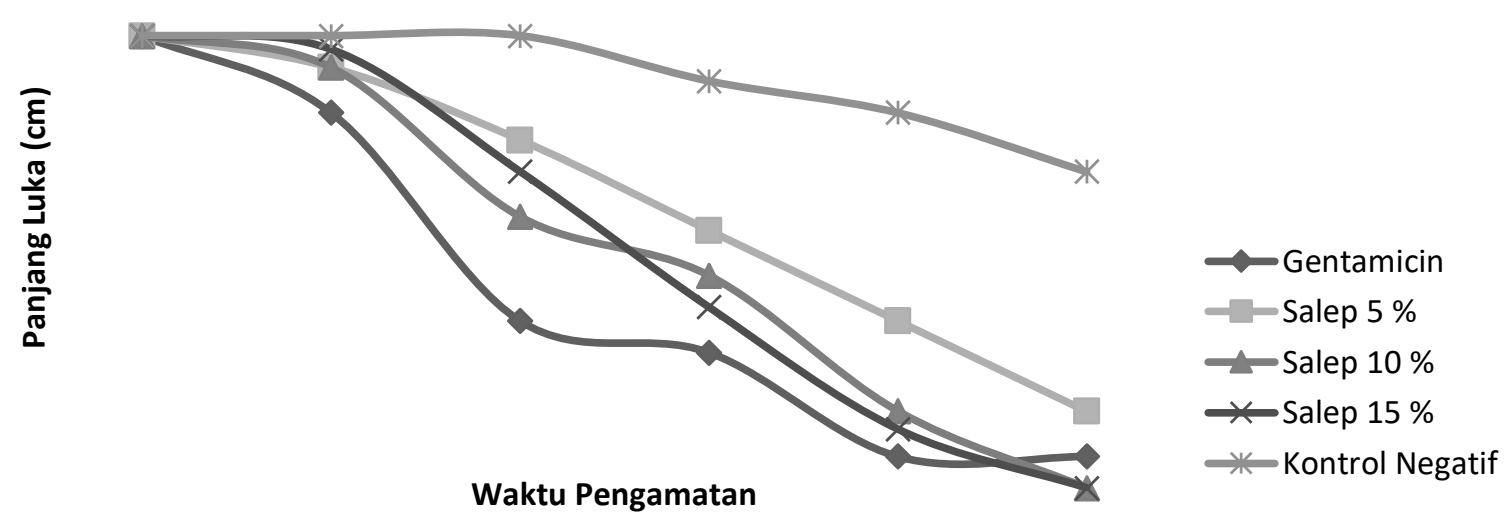

Gambar 2. Penurunan Panjang Luka

Berdasarkan data pada grafik diatas terlihat penurunan panjang luka pada setiap kelompok. Penurunan yang begitu signifikan terlihat pada mencit dengan kelompok pemberian salep gentamicin (kontrol positif), salep ekstrak 10\% dan 15\%. Penurunan panjang luka disebabkan oleh kandungan tanin dan flavonoid yang terdapat pada limbah kulit singkong. Dimana semakin tinggi jumlah ekstrak yang digunakan, semakin tinggi kandungan tannin dan flavonoid yan ada, sehingga semakin tinggi pula penurunan panjang luka yang dihasilkan.

Pada awal tahap penyembuhan luka akan terjadi fase inflamasi yang menyebabkan pembentukan Reactive Oxygen Species (ROS). ROS dihasilkan dari neutrofil dan makrofag sebagai bagian dari system imun yang membantu mempercepat perbersihan luka dari serangan bakteri. Namun, keberadaan ROS dalam kadar tinggi dapat merusak jaringan secara berat 
(Kurahashi dan Fuji, 2015). Sehingga keberadaan ROS didalam tubuh dalam jangka waktu yang lama dapat menghambat proses penyembuhan luka.

Pemodelan luka hewan dengan menggunakan bakteri Staphylococcus aureus menggambarkan kejadian luka secara umum, khususnya pada kejadian gangrene akibat komplikasi diabetes. Pengobatan diabetes tidak cukup hanya dengan menurunkan kadar gula darah saja, tetapi memerlukan terapi kombinasi untuk mengatasi komplikasi yang muncul. Saat ini terapi penurun gula darah maupun komplikasinya beralih menggunakan bahan alam. Sebagai contoh Brucea javanica (L) mer yg mampu menurunkan gula darah puasa pada hewan diabetes melalui retorasi pulau Langerhans pankreas (Muliasari, 2017).

Salep ekstrak etanol kulit singkong memiliki beberapa kandungan yang dapat menstabilkan ROS, salah satunya adalah flavonoid. Flavonoid bersifat antioksidan kuat, berperan menstabilkan ROS sehingga dapat mempercepat penyembuhan luka dengan mekanisme meningkatkan proliferasi sel epitel dan kolagen. Selain itu, juga dapat meningkatkan fungsi dari antioksidan endogen serta memperbesar level enzim antioksidan dalam jaringan granulasi (Keller dkk, 2006). Antioksidan endogen salah satunya asam askorbat dibutuhkan dalam sintesis kolagen, flavonoid memiliki kandungan antiskorbut yang dapat melindungi asam askorbat dari ROS (Hartanto, 2013) dengan cara menghambat siklooksigenase dan lipooksigenase, sehingga jumlah sel inflamasi yang bermigrasi ke jaringan luka berkurang, yang menyebabkan reaksi inflamasi dan waktu terpaparnya jaringan luka terhadap ROS menjadi lebih singkat (Napanggala dkk, 2012). Sehingga proses sintesis kolagen dapat berjalan lancar. Flavonoid juga bekerja sebagai antiinflamasi dengan menghambat COX2 yang selanjutnya menghambat pembentukan prostalglandin E2 sehingga proses inflamasi berkepanjangan dapat dicegah dan respon peradangan seperti nyeri dan bengkak dapat dihentikan (Huang, 2006).

Tanin berfungsi sebagai antibakteri dan astringen yang dapat menghentikan eksudat dan pendarahan ringan (Wijaya, 2014). Astringent merupakan bahan pengencang yang mempunyai daya untuk mengerutkan dan menciutkan jaringan kulit, sehingga pendarahan pada luka dapat berhenti lebih cepat dan luka cepat mengering (Samuelsson, 1999).

\section{Perhitungan Jumlah Leukosit}

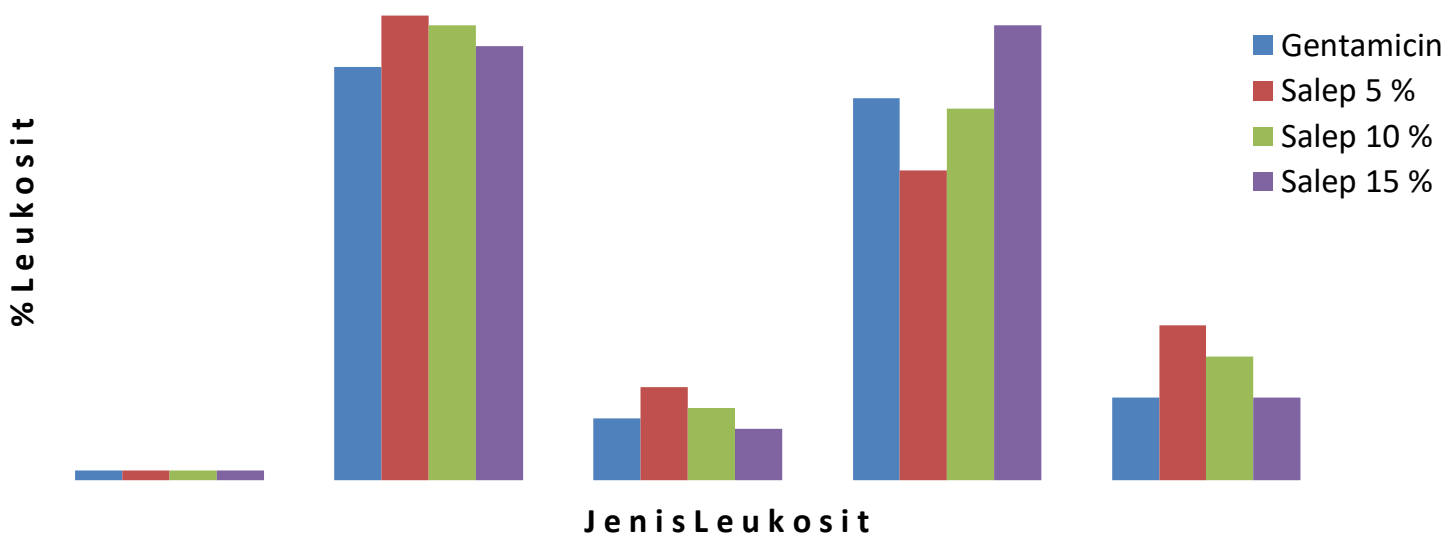

Gambar 3. Perhitungan Jumlah Leukosit 
Bedasarkan grafik diatas terjadi penurunan jumlah sel monosit yang diduga terjadi karena karena monosit berdiferensiasi menjadi sel makrofag dan menetap di jaringan (Kresno, 1991). Terjadi peningkatan jumlah sel limfosit yang berbanding lurus dengan peningkatan dosis, terutama pada pemberian dosis $15 \%$ dan salep gentamicin terdapat peningkatan yang signifikan. Dengan demikian ekstrak etanol limbah kulit singkong dapat meningkatkan jumlah sel limfosit yang juga dapat mernagsang respon imun. Telah di laporkan beberapa ekstrak bahan alam memiliki aktivitas pada sistem imun baik sebagai imunomodulator ataupun imunosupresan. Sebagai contoh ekstrak petroleum ether daun ara yang mempengaruhi aktifitas makrofag (Trihastuty, 2019).

\section{KESIMPULAN}

Salep ekstrak etanol limbah kulit singkong memiliki efek pada proses penyembuhan luka dilihat dari penurunan panjang luka. Salep ekstrak etanol limbah kulit singkong yang memberikan efek lebih baik dalam penyembuhan luka adalah salep dengan kosentrasi $10 \%$ dan $15 \%$.

\section{Ucapan Terimakasih}

Peneliti mengucapkan terima kasih kepada Kemenristekdikti atas dana yang diberikan melalui Pekan Kreativitas Mahasiswa (PKM) 2019

\section{DAFTAR PUSTAKA}

Badan Pusat Statistik, 2017, "Produksi Tanaman Ubi Kayu Menurut Provinsi (ton) Tahun 1993-2015”, (Online), (http://www.bps.go.id/linkTableDinam is/view/id/880., diakses tanggal 12 Februari 2017 pukul 14.03 WITA.

Hartanto, Tony. 2013. Pengaruh Antimikroba Ekstrak Kulit Manggis (Garcinia Mangostana L.) Terhadap Pertumbuhan Shigella dysenteriae Secara in Vitro. FK Universitas Islam Sultan Agung.

Hikmiyati, N., dan Yantie, N. S., 2008. Pembuatan Bioetanol dari Limbah Kulit Singkong Melalui Proses Hidrolisa Asam dan Enzimatis. Undip.

Huang, Y.L., Cheng, L.Y., Sheu, S.J., and Chen, C.C. 2006. Bioactive Flavonoids from Ruellia tuberosa. J Chin. Med. 17 (3): 103-109.

Kawulusan, R.F., Kalangi, R.J.S., dan Kaseke, M.M. 2015. Gambaran Reaksi Radang Luka Antemortem yang Diperiksa 1 Jam Postmortem Pada Hewan Coba. Jurnal eBiomedik, 2 (1): 393-397.

Keller, U., Kumin, A., Braun, S., dan Werner, S. 2016. Reactive Oxygen Species and Their Detoxification in Healing Skin Wounds. Journal of Investigative Dermatology Symposium Proceedings.

Kresno, B.G. 1991. Imunologi: Diagnosis dan Prosedur Laboratorium, (Edisi III). Jakarta: FK Universita Indonesia.

Kurahashi, T., dan Fuji., J. 2015. Roles of Antioxidative Enzymes in Wound Healing. Journal of Developmental Biology. 
Muliasari, H., C.D, Hamdin., A.D, Ananto., dan M. Ihsan. 2017. Hypoglycemic Effect of Brucea javanica (L) Merr Leaves and Seed Extractin Alloxan-induced Diabetic Rats. Mataram: Proceeding of $2^{\text {nd }}$ ICST 2017.

Mutiara, Gadis., Nurdiana., dan Yulian Wiji Utami. 2015. Efektifitas Hidrogel Binahong (Anredera cordifolia (Ten.) Steenis) terhadap Penurunan Jumlah Makrofag pada Penyembuhan Luka Fase Proliferasi Tikus Putih (Rattus norvegicus) Galur Wistar Kondisi Hiperglikemia. Majalah Kesehatan FK Universitas Brawijaya.

Safani, E.E., Kunharjito. W.A.C., Lestari A. dan Purnama, R. 2019. Potensi Ekstrak Daun Bandotan (Ageratum conyzoides L.) Sebagai Spray untuk Pemulihan Luka Mencit Diabetik Yang Terinfeksi Stahpylococcus aureus (ISSN: 2580-5029).

Samuelsson G. 1999. Drugs of natural origin. 4th ed. Apotekar Societeten. Stockhol

Trihastuty, A., S.R, Aini., C.D, Hamdin. 2019. Efek Ekstrak Petroleum Eter Daun Ara (Ficus racemose Linn.) pada Indeks Fagositosis Mencit (Mus musculus). (ISSN: 26146495).

Venita dan Budiningsih, Y. 2014. Forensik pada Kasus Perlukaan (Traumatologi). In C. Tanto dkk. eds. Kapita Selekta Kedokteran Jilid II. Jakarta: Media Aesculapius, hal. 888891.

Wijaya, B.F., Citraningtyas, G., dan Wehantouw F. 2014. Potensi Ekstrak Etanol Tangkai Daun Talas (Colocasia esculenta L) Sebagai Alternatif Obat Luka Pada Kulit Kelinci (Oryctolagus cuniculus) ISSN: 2302-2493. 